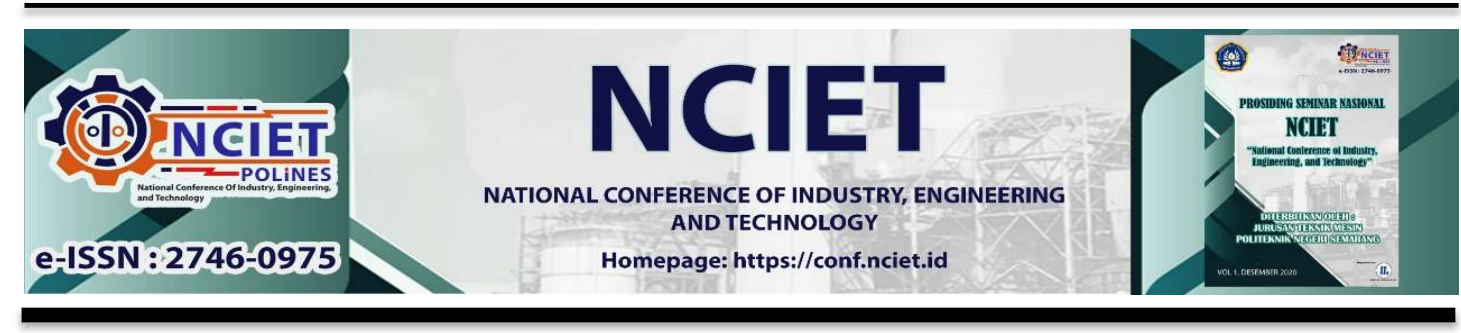

Prosiding Seminar Nasional NCIET Vol.1 (2020) B336-B341

$1^{\text {st }}$ National Conference of Industry, Engineering and Technology 2020,

Semarang, Indonesia.

\title{
ANALISA EFISIENSI BATERAI 110 VOLT DI PT. PLN(PERSERO) GARDU INDUK 150 KV PATI
}

\section{Titania Salza Dilla*'Margono, Ken Hasto}

Teknik Elektro, Fakultas Teknik dan Informatika, Universitas PGRI Semarang

Jl. Sidodadi Timur No.24 Dr. Cipto, Karang Tempel, Semarang, 50232

*E-mail : E-mail : Tita.nia7689@gmail.com ; upgris@upgris.ac.id

\begin{abstract}
Abstrak
Baterai adalah suatu alat yang dapat menghasilkan energi listrik dengan proses kimia. Yang dimaksud proses kimia adalah di dalam baterai dapat berlangsung proses pengubahan kimia menjadi tenaga listrik (proses pengosongan) dan sebaliknya proses tenaga listrik menjadi tenaga kimia (pengisian kembali) dengan cara regenerasi elektroda-elektroda yang dipakai yaitu dengan melewatkan arus listrik dalam arah polaritas yang berlawanan di dalam sel. Kapasitas suatu baterai merupakan besar arus listrik (ampere) baterai yang dapat dialirkan ke suatu rangkaian luar (beban), dalam jangka waktu tertentu (jam), untuk memberikan tegangan tertentu sehingga dari pengujian kapasitas dapat ditentukan efisiensi baterai. Efisiensi suatu baterai didefinisikan sebagai persentase ratio atau perbandingan dari kapasitas pengosongan terhadap kapasitas pengisian. Dari grafik pengukuran charger on selama empat tahun dari bulan Januari sampai Desember menunjukkan bahwa nilai data yang didapatkan $>1.40$ Volt, sehingga dikategorikan dalam standart tegangan floating menurut standart IEC 623 tegangan floatingnya sebesar 1.40 Volt. Pada hasil pengujian kapasitas baterai merk Saft Nife didapatkan efisiensi selama empat tahun yaitu pada Tahun 2016 sebesar 99.27\%, Tahun 2017 sebesar 98.75\%, Tahun 2018 sebesar 98.17\%, dan Tahun 2019 sebesar 98.02\%. Sehingga persentase efisiensi baterai masih dalam kategori baik menurut standart SE032 sebesar 80\%. Sehingga efisiensi selama empat tahun dari tahun 2016 sampai 2019 diperoleh data bahwa pada tahun 2016 mempunyai efisiensi yang tinggi sebesar 99.27\%. Maka, pada tahun 2016 sampai 2019 mengalami penurunan yang stabil karena pemeliharaan dan uji kapasitasnya bagus sehingga penurunannya tidak begitu drastis dan masih signifikan.
\end{abstract}

Kata Kunci: Baterai; Disharge; Uji Kapasitas; Tegangan Floating; Efisiensi baterai

\section{PENDAHULUAN}

Perkembangan dan kemajuan teknologi yang semakin berkembang pesat, energi listrik memegang peranan yang sangat penting dalam menopang pembangunan dan kemajuan tersebut. Melihat hal tersebut, penyediaan energi listrik diharuskan mampu memenuhi 
kebutuhan yang diperlukan konsumen secara kontinyu dan kualitas yang baik, maka dengan terpenuhinya kebutuhan energi listrik konsumen dengan jumlah yang dibutuhkan dan kualitas baik akan terwujud kemakmuran untuk manusia dan teknologi tetap terus berkembang.

\section{METODE PENELITIAN}

Pada penelitian ini dilakukan untuk mengamati proses efisiensi baterai pada Gardu Induk dengan cara mengamati proses charging dan discharging, pengukuran tegangan dan berat jenis persel pada saat kondisi charge on dan off, pengukuran kapasitas baterai, pengukuran tegangan total baterai pengisian floating, menghitung dan menganalisa data pabrikan baterai dan uji kapasitas, kemudian mengukur tegangan, suhu, berat jenis elektrolit kemudian mengolah data dengan perhitungan efisiensi baterai.

\section{HASIL DAN PEMBAHASAN}

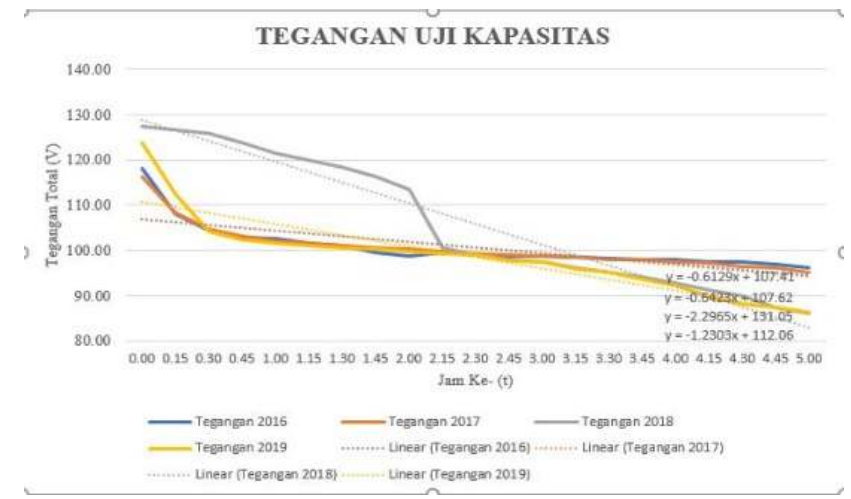

Grafik 4.1 Tegangan Uji Kapasitas

Dari Grafik di atas diperoleh data bahwa pada tahun 2019 mengalami penurunan paling rendah dibandingkan tahun tahun sebelumnya dibuktikan juga dengan adanya garis linear y $=-1.2303 \mathrm{x}+112.06$. Dari data tegangan uji kapasitas tersebut mengalami penurunan yang signifikan dibuktikan adanya tegangan charger on banyak yang rusak di tahun 2019 dengan grafik di bawah ini yaitu tegangannya di bawah standar floating 1.4 Volt. 


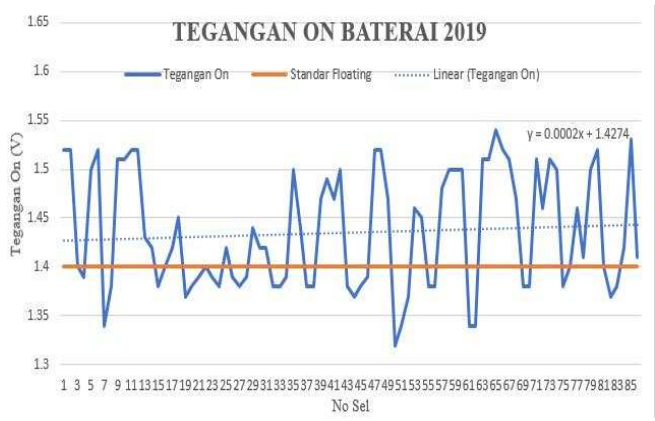

Grafik 4.2 Tegangan On Rusak 2019

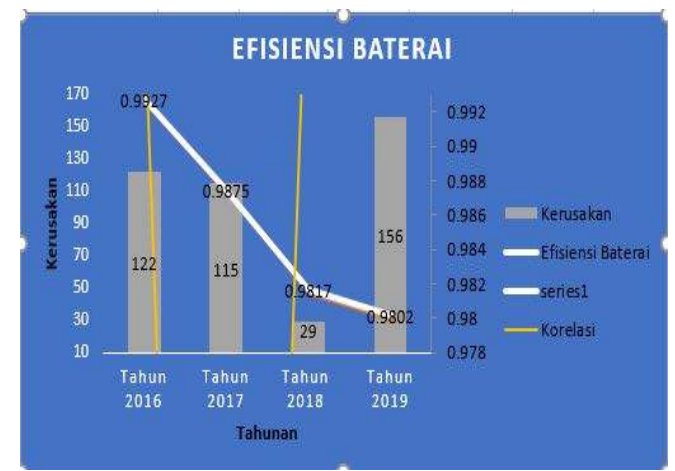

Grafik 4.3 Grafik Koefisien Korelasi dengan Efisiensi baterai

Dengan adanya grafik perhitungan koefisien korelasi dapat diketahui bahwa efisiensi yang paling standart dari acuan data tahun 2016. Untuk mengetahui rumus koefisien korelasi dapat dicari sebagai berikut

$$
\begin{array}{r}
r=\sqrt{\frac{D t^{2}-D^{2}}{D t^{2}}} \\
\text { dengan, } r=\text { koefisien korelasi } \\
D t^{2}=\sum_{i=1}^{n}\left(y_{i}-\bar{y}\right)^{2} \\
D^{2}=\sum_{i=1}^{n}\left(y_{i}-a-b x\right)^{2} \\
=\sum_{i=1}^{n}\left(y_{i}-g\left(x_{i}\right)\right)^{2}
\end{array}
$$

Perhitungan dan Efisiensi Baterai yang digunakan adalah jenis baterai Alkali Saft Nife SBM 208. Maka settingan waktu yang digunakan adalah 5 jam. Adapun tegangan akhir per selnya 
mengambil batas minimum 1 Volt/sel, maka settingan tegangan minimum totalnya 86 Volt. Pada arus pengosongan dibuat konstan sebesar 41.6 Ampere. Efisiensi data baterai di ambil selama 4 tahun dari 2016 sampai 2019.

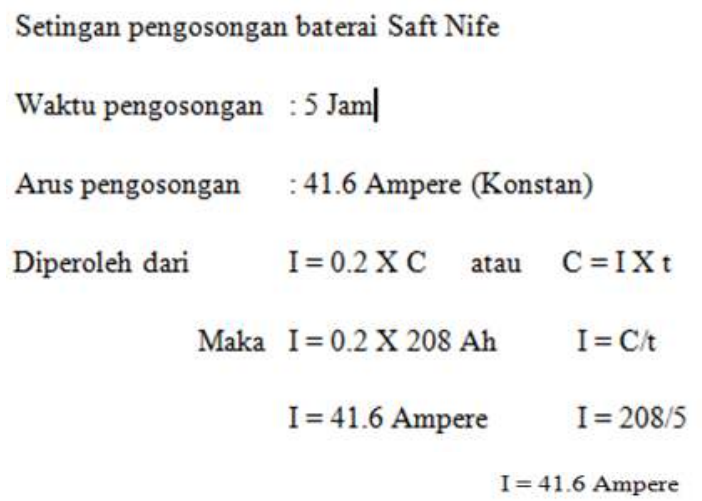




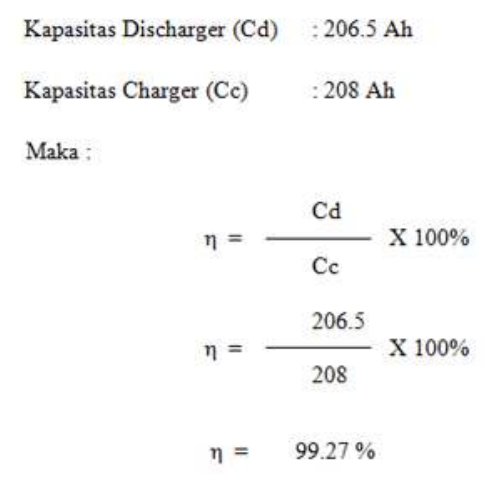

Jadi Efisiensi Baterai Saft Nife SBM 208 Tahun 2016 sebesar $99.27 \%$

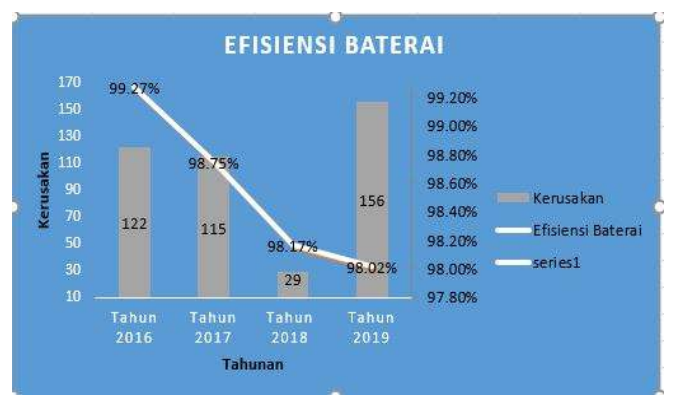

Gambar 4.4 Grafik Efisiensi Baterai 2016201720182019

Dari grafik efisiensi selama empat tahun dari tahun 2016 sampai 2019 diperoleh data bahwa pada tahun 2016 mempunyai efisiensi yang tinggi sebesar 99.27\%. Efisiensi baterai saft nife type sbm 208 selama empat tahun tersebut masih dalam kategori baik sekali menurut standart SE032 karena standart kategori efisiensinya baik sebesar 80\%. Dari tahun 2016 sampai 2019 mengalami penurunan yang stabil karena pemeliharaan dan uji kapasitasnya bagus sehingga penurunannya tidak begitu drastis dan masih signifikan.

\section{KESIMPULAN}

Berdasarkan hasil pengukuran dari pemeliharaan dan uji kapasitas baterai 110 volt pada Gardu Induk Pati yang telah dilakukan didapatkan kesimpulan bahwa sebagai berikut :

1. Dari hasil pengukuran Floating (Charger on) baterai merk Saft Nife Type SBM 208 selama empat tahun didapatkan pada tahun 2019 mengalami kerusakan parah sebanyak 156 sel dengan rata rata tegangan on rusak sebesar 1.38493 Volt. Dibuktikan juga dengan grafik tegangan uji kapasitas dan gradiennya sebsar $\mathrm{y}=-1.2303 \mathrm{x}+112.06$.

2. Standart tegangan floating menurut standart IEC 623 tegangan floatingnya sebesar 1.40 Volt. 
3. Penting adanya suatu ketaatan melakukan jadwal maintenance/pemeliharaan terhadap alat - alat sesuai dengan aturan yang sudah ditentukan. Hal ini bertujuan untuk bisa menghindari kerusakan mendadak yang tergolong fatal.

4. Pada hasil pengujian kapasitas baterai merk Saft Nife Type SBM 208 pada Gardu Induk 150 KV Pati didapatkan efisiensi selama empat tahun yaitu pada Tahun 2016 sebesar 99.27\%, Tahun 2017 sebesar 98.75\%, Tahun 2018 sebesar 98.17\%, dan Tahun 2019 sebesar 98.02\%. Sehingga persentase efisiensi baterai masih dalam kategori baik menurut standart SE032 sebesar $80 \%$.

5. Dari grafik efisiensi selama empat tahun dari tahun 2016 sampai 2019 diperoleh data bahwa pada tahun 2016 mempunyai efisiensi yang tinggi sebesar 99.27\%. Maka, pada tahun 2016 sampai 2019 mengalami penurunan yang stabil karena pemeliharaan dan uji kapasitasnya bagus sehingga penurunannya tidak begitu drastis dan masih signifikan.

\section{DAFTAR PUSTAKA}

Aminullah, M.Yuri. (2017). Penggantian Battere 110V Unit 1 GI Jekulo. Pati: Laporan Pelaksanaan On The Job Training Prajabatan Tingkat SMK-Jalur Pelaksana.

Bakhtiar \& Tadjuddin. (2016). Peningkatan Efisiensi Pengisian Baterai Pembangkit Listrik Tenaga Surya. Makassar: Politeknik Negeri Ujung Pandang.

Cahyo A, N. (2013). Pemeliharaan Tahunan Sistem DC (Baterai 48 Volt Unit II) di Gardu Induk $150 \mathrm{KV}$. Srondol: Universitas Diponegoro.

Iklil, M., \& Warsito, A. (2014). Sistem DC 220V PLTU Pacitan 2x315 MW. Semarang: Universitas Diponegoro.

Muhammad Chanif, Sardono Sarwito, \& Eddy Setyo. (2014). Analisa Pengaruh Penambahan Kapasitor Terhadap Proses Pengisian Baterai Wahana Bawah Laut. Surabaya: Institut Teknologi Sepuluh November (ITS).

Nurhalim, R. A. (2016). Studi Kapasitas Baterai 110 Vdc Pada Gardu Induk $150 \mathrm{Kv}$ Bangkinang. Riau: Universitas Riau

Pamudji, Nur. (2014). Buku Pedoman Sistem Suplai ACDC. Jakarta: PLN.

Rifa'i, A. M. (2019). Analisis Uji Kapasitas Baterai 110 VDC Pada Gardu Induk 150 KV Klaten. Surakarta: Universitas Muhammadiyah Surakarta.

Rifa'i, M. H. (2019). Analisis Kebutuhan Kapasitas Baterai 110 Volt DC Gardu Induk 150KV Bawen. Surakarta: Universitas Muhammadiyah Surakarta.

Salam, I. (2007). Analisis Baterai Komunikasi Pada Gardu Induk PT. PLN Region Jateng dan DIY UPT Kudus. Semarang: Universitas Negeri Semarang.

Syahrial, B. M. (2019). Analisa Pengaruh Berat Jenis Dan Suhu Larutan Elektrolit Terhadap Tegangan Keluaran Dan Efisiensi Baterai di PT. PLN UPK Bukit Asam. Indralaya: Universitas Sriwijaya. 